\title{
THE RELATIONSHIP BETWEEN INSULIN RESISTANCE AND CARDIOVASCULAR SYSTEM DISORDERS
}

\section{POVEZANOST INSULINSKE REZISTENCIJE I POREMEĆAJA KARDIOVASKULARNOG SISTEMA}

\author{
Danijela Vučević', Bojan Jorgačević', Tatjana Radosavljević', Đorđe Radak², Davor Kovačević1
}

\begin{abstract}
Summary
The metabolic syndrome is a cluster of more or less related metabolic and cardiovascular derangements including visceral obesity, insulin resistance, dislipidemia, hypertension and glucose intolerance. This syndrome is characterized by a primary cellular defect in insulin action due to disorders in insulin signal transduction (insulin is unable adequately to achieve its biological effects). Under these conditions, insulin resistance, in combination with hyperinsulinemia causes a numerous metabolic and cardiovascular disorders, that are leading cause of morbidity and mortality worldwide. From pathophysiological point of view, insulin resistance, as well as adipokines and fatty acids released from metabolically active visceral fat tissue, significantly contributes to development of many chronic diseases (diabetes mellitus /diabetes mellitus/ type 2, hypertension, accelerated atherosclerosis and its cardiovascular and cerebrovascular complications, nonalcoholic fatty liver disease, polycystic ovary syndrome and some malignant diseases / breast cancer, etc./). Having in mind increase of metabolic syndrome prevalence in future, it is necessary to take preventive actions to decrease risk factors (inappropriate diet rich in carbohydrates and saturated fat, obesity, smoking, sedentary lifestyle and physical inactivity). Except to lifestyle changes, usage of hypocaloric diet and increase level of physical activity, in patients with metabolic syndrome it is necessary to apply appropriate medical treatment of some components of the syndrome. Although a numerous studies related to this global medical problem are carrying out, scientists are still far from a complete understanding of the molecular basis of this problem.
\end{abstract}

Keywords: insulin resistance, cardiovascular derangements, obesity, atherosclerosis

\section{Sažetak}

Metabolički sindrom predstavlja udruženu pojavu intolerancije glukoze, arterijske hipertenzije, dislipidemije, centralnog (abdominalnog, visceralnog) tipa gojaznosti, kao i postojanje drugih metaboličkih poremećaja u čijoj se osnovi nalazi insulinska rezistencija. Ovaj sindrom prevashodno odlikuje primarni ćelijski defekt dejstva insulina, tj. insulin usled defekta u signalnoj transdukciji nije u mogućnosti da ostvari svoje biološke efekte. U takvim uslovima, insulinska rezistencija u kombinaciji sa posledičnom hiperinsulinemijom izaziva brojne metaboličke i kardiovaskularne poremećaje, koji imaju pandemijski karakter i predstavljaju vodeći uzrok morbiditeta i mortaliteta u svetu. U patofiziološkom smislu, insulinska rezistencija, adipokini i masne kiseline koje oslobađa metabolički aktivno visceralno masno tkivo značajno doprinose nastanku i razvoju širokog spektra hroničnih nezaraznih bolesti, kao što su dijabetes melitus (diabetes mellitus) tip 2, hipertenzija, ubrzana ateroskleroza sa svojim kardiovaskularnim i cerebrovaskularnim komplikacijama, nealkoholna masna bolest jetre, sindrom policističnih ovarijuma i pojedine maligne bolesti (karcinom dojke i dr.). Imajući u vidu tendenciju sve većeg porasta prevalencije metaboličkog sindroma u narednim dekadama, neophodno je preduzimanje preventivnih mera za suzbijanje faktora rizika na koje se može uticati (neodgovarajuća ishrana bogata ugljenim hidratima i zasićenim masnim kiselinama, gojaznost, pušenje, sedentarni način života i fizička neaktivnost). 0sim promene stila života, primene hipokaloriijke dijete i povećanja fizičke aktivnosti, kod bolesnika sa metaboličkim sindromom neophodna je i primena odgovarajuće medikamentne terapije pojedinih komponenti sindroma. Stoga su neophodna dalja istraživanja molekulskih mehanizama ovog sindroma, kako bi se sprečio njegov nastanak, odnosno pronašao efikasniji terapijski pristup.

Ključne reči: insulinska rezistencija, kardiovaskularni poremećaji, gojaznost, ateroskleroza

UvoD

Bolest nam ne dolazi iz vedra neba, već se razvija iz svakodnevnih malih grehova prema prirodi.

Hipokrat

Metabolički sindrom predstavlja udruženu pojavu intolerancije glukoze, arterijske hipertenzije, dislipidemije, centralnog (abdominalnog/visceralnog/) tipa gojaznosti, kao i postojanje drugih metaboličkih poremećaja u čijoj se osnovi nalazi insulinska rezistencija. Ovaj sin- drom prevashodno odlikuje primarni ćelijski defekt dejstva insulina, tj. insulin usled neadekvatne signalne transdukcije nije u mogućnosti da ostvari svoju biološku ulogu. U takvim uslovima, insulinska rezistencija u kombinaciji sa posledičnom hiperinsulinemijom izaziva brojne metaboličke i kardiovaskularne poremećaje, koji imaju pandemijski karakter i predstavljaju vodeći uzrok morbiditeta i mortaliteta u svetu (1).

Metabolički sindrom je klinički entitet koji značajno doprinosi nastanku i razvoju širokog spektra hroničnih nezaraznih bolesti, kao što su šećerna bolest (dijabetes 
melitus /diabetes mellitus/) tip 2 (ranije označen kao insulin-nezavisni dijabetes melitus), arterijska hipertenzija, ubrzana ateroskleroza sa svojim kardiovaskularnim i cerebrovaskularnim komplikacijama, nealkoholna masna bolest jetre (NAFLD, engl. nonalcoholic fatty liver disease), sindrom policističnih ovarijuma i pojedine maligne bolesti (karcinom dojke, i dr.) (2). Ovaj veoma čest skup patofizioloških poremećaja koji imaju metaboličko poreklo, označen još kao sindrom X i sindrom insulinske rezistencije, prisutan je kod približno svake četvrte odrasle osobe (3). On ujedno predstavlja faktor rizika za razvoj bolesti srca i krvnih sudova, pa se zbog toga naziva „smrtonosni kvartet“(4).

Postoji više različitih definicija metaboličkog sindroma. U kliničkoj praksi se najčešće koriste definicije koje su dali stručnjaci Međunarodnog udruženja za borbu protiv dijabetesa (IDF, engl. International Diabetes Federation), kao i eksperti Američkog udruženja za borbu protiv bolesti srca (AHA, engl. American Heart Association) i NHLBI (engl. National Heart, Lung and Blood Institute) (5). Shodno IDF konsenzusu, metabolički sindrom predstavlja prisustvo abdominalne gojaznosti koja je specifična za pojedine populacije (Tabela 1), zajedno sa najmanje još dva kriterijuma iz sledeće grupe (koncentracija triglicerida/TG/ u plazmi veća od 1.7 $\mathrm{mmol} / \mathrm{L}$ ili medikamentno lečenje hipertrigliceridemije; nivo lipoproteina velike gustine /HDL, engl. high density lipoprotein/ u plazmi niži od $1.03 \mathrm{mmol} / \mathrm{L} \mathrm{kod}$ muškaraca, odnosno ispod $1.3 \mathrm{mmol} / \mathrm{L}$ kod žena; arterijski krvni pritisak veći od 130/85 $\mathrm{mmHg}$ ili farmakološka terapija arterijske hipertenzije; glikemija našte iznad $5.6 \mathrm{mmol} / \mathrm{L}$ ili prethodno dijagnostikovan dijabetes melitus tip 2) (6).

Tabela 1. Kriterijumi IDF za visceralnu gojaznost u metaboličkom sindromu

Table 1. IDF criteria for visceral obesity in metabolic syndrome

$\begin{array}{lcc}\text { Etnička pripadnost } & \text { Pol } & \text { Obim struka }(\mathbf{c m}) \\ \text { Evropa } & \text { muški } & \geq 94 \\ & \text { ženski } & \geq 80 \\ \text { Južna Azija } & \text { muški } & \geq 90 \\ & \text { ženski } & \geq 80 \\ \text { Japan } & \text { muški } & \geq 90 \\ & \text { ženski } & \geq 80 \\ \text { Kina } & \text { muški } & \geq 90 \\ & \text { ženski } & \geq 80 \\ \text { Južna i Centralna Amerika } & \text { muški } & \geq 90 \\ & \text { ženski } & \geq 80 \\ \text { Subsaharska Afrika } & \text { muški } & \geq 94 \\ & \text { ženski } & \geq 80 \\ \text { Istočni Mediteran i Srednji Istok } & \text { muški } & \geq 94 \\ & \text { ženski } & \geq 80\end{array}$

Eksperti AHA i NHLBI prihvatili su IDF kriterijume za kliničku dijagnozu metaboličkog sindroma, pri čemu je prisustvo centralne gojaznosti verifikovano obimom struka većim od $102 \mathrm{~cm}$ kod muškaraca, odnosno većim od $88 \mathrm{~cm}$ kod žena (7). Uz to, za sagledavanje celokupne slike metaboličkog sindroma, naročito kod dijabetičara i obolelih od kardiovaskularnih bolesti, IDF konsenzus naglašava potrebu dodatnog ispitivanja distribucije masnog tkiva, insulinske rezistencije, lipidnog statusa i vaskularne funkcije. Pored toga, neophodno je i određivanje hormonskog statusa (hipofizno-adrenalna osovina), medijatora zapaljenjskog procesa (C-reaktivni protein /CRP/, inflamacijski citokini, adiponektin, i dr.), kao i faktora koji učestvuju u koagulaciji (fibrinogen, i dr.) i fibrinolizi (6).

Metabolički sindrom je zasnovan na interakciji endogenih (genetskih) faktora i egzogenih faktora (gojaznost, fizička neaktivnost, unos hrane velike energetske gustine /hrana bogata ugljenim hidratima i mastima/, uzrast, pol, rasa, pozitivna porodična anamneza gojaznosti i/ili arterijske hipertenzije i/ili šećerne bolesti, otežano prilagođavanje stresnim situacijama, hronični stres, i dr.), koji dovode do nastanka insulinske rezistencije i povećanja količine visceralnog masnog tkiva (8).

\section{INSULINSKA REZISTENCIJA I DISFUNKCIJA KARDIOVASKULARNOG SISTEMA}

Metabolički sindrom je najviše odgovoran za razvoj kardiovaskularnih oboljenja u poslednjoj deceniji (9). Osobe sa metaboličkim sindromom imaju dva puta veći rizik za nastanak mortaliteta usled kardiovaskularnog oboljenja i tri puta veći rizik da obole od infarkta miokarda ili moždanog udara u odnosu na zdrave osobe. Uz to, ove osobe imaju i višestruko veći rizik da obole od dijabetesa tip 2 (5). Takođe, sve komponente metaboličkog sindroma su nezavisni uzročnici kardiovaskularnih događaja, kao što su moždani udar, kardiomiopatija, bolest koronarnih arterija, infarkt miokarda, srčana insuficijencija i iznenadna srčana smrt (10).

U okolnostima kada normalna koncentracija insulina proizvodi smanjeni biološki odgovor i nedovoljno preuzimanje glukoze, javlja se insulinska rezistencija. $\mathrm{S}$ tim u vezi, primarni defekt je vezan za receptorski sistem perifernih tkiva, uzrokujući povećanu sekreciju insulina. Shodno tome, nastaje hiperinsulinemija, koja nije efikasna zbog postojeće rezistencije na delovanje insulina. Vremenom hiperinsulinemija koja je imala za cilj da održi euglikemiju (naročito u postprandijalnom periodu) dovodi do postepenog iscrpljivanja insulinskih rezervi u pankreasu, sa posledičnim smanjenim stvaranjem insulina (11). Naime, konstantna hiperglikemija predstavlja metabolički stres za mitohondrije $\beta$ ćelija pankreasa. U takvim uslovima povećava se produkcija slobodnih radikala, koji u prvo vreme dovode do oštećenja mitohondrija sa sledstvenim smanjenim stvaranjem adenozin trifosfata (ATP) i insulina, a kasnije dolazi do apoptoze $\beta$ ćelija pankreasa i razvoja dijabetes melitusa tip 2 (12). 
Insulinska rezistencija, kako na receptorskom nivou (snižena tirozin autofosforilacija), tako i na postreceptorskom nivou (snižen transport glukoze, smanjeno stvaranje sekundarnih transmitera), bitno doprinosi nastanku poremećaja metabolizma lipida, gojaznosti i kardiovaskularnih oboljenja (1-6, 11-15). Ona može biti periferna (smanjenje insulinom posredovanog preuzimanja glukoze u skeletne mišiće i masno tkivo) i hepatična (onemogućenost insulina da smanji produkciju glukoze u jetri) (16).

Tabela 2. Uzroci insulinske rezistencije u gojaznosti

Table 2. Causes of insulin resistance in obesity

Genetski faktori
ob gen (leptin)
$\beta_{3}$-adrenergijski receptori
Faktor tumorske nekroze-alfa (TNF- $\alpha$ )
Parametri u cirkulaciji
Povišena koncentracija slobodnih masnih kiselina
Povišen nivo insulina
Povišena vrednost glukoze
Povišen sadržaj polnih hormona
Morfološki pokazatelji
Snižena oksidacijska sposobnost mišićnih vlakana
Povećana masa visceralnog masnog tkiva
Smanjena gustina kapilara
Smanjen protok krvi u mišićima

Mehanizam kojim insulinska rezistencija dovodi do kardiovaskularnih oboljenja je kompleksan i svodi se na promenu intraćelijskih signalnih puteva, što rezultuje povećanom produkcijom endotelina i stimulacijom transkripcije proinflamacijskih gena, sa posledičnom povećanom tendencijom ka koagulaciji (5). U stanjima visoke koncentracije insulina, usled homologije insulina sa insulinu sličnim faktorom rasta-1 (IGF-1, engl. insulin-like growth factor-1), u tkivima kardiovaskularnog sistema, kao i u drugim tkivima senzitivnim na insulin (skeletni mišići i masno tkivo), može da dođe do vezivanja insulina za receptor za IGF-1 (IGFR-1) i njegove stimulacije (17).

Gojaznost. Pretpostavlja se da insulinska rezistencija koja se javlja usled gojaznosti predstavlja prvi korak u razvoju kardiovaskularnih oboljenja. Uzroci insulinske rezistencije u gojaznosti nisu u potpunosti proučeni (Tabela 2).

$\mathrm{U}$ tom pogledu su posebno važne slobodne masne kiseline (SMK), s obzirom da je njihova koncentracija povišena, a metabolizam izmenjen u osoba sa visceralnom gojaznošću (18). Naime, neželjeni efekti povećane infiltracije SMK u različite organe i tkiva su označeni terminom lipotoksičnost (19). Ovaj termin obuhvata ćelijsko oštećenje i smrt ćelija koji nastaju dejstvom SMK, njihovih metabolita i TG, iako se TG smatraju relativno inertnim u tom smislu. Mehanizmi toksičnosti masnih kiselina su raznovrsni, imajući u vidu da masne kiseline mogu da daju veliki broj produkata koji se razlikuju po dužini lanca, mestu desaturacije, kao i cis i trans konfiguraciji dvostrukih veza (20). Tako, povećano oslobađanje SMK prati porast njihove oksidacije, što inhibitorno deluje na oksidaciju glukoze. Zbog intenzivnije $\beta$-oksidacije dolazi do porasta acetil-koenzim A (acetilCoA)/CoA odnosa, kao i odnosa između nikotinamid adenin dinukleotida u redukovanom (NADH) i oksidovanom $\left(\mathrm{NAD}^{+}\right)$obliku u mitohondrijama, što posledično dovodi do inaktivacije piruvat dehidrogenaze. Time je onemogućeno konvertovanje piruvata u acetil-CoA, pa intracelularno nakupljanje citrata izaziva inhibiciju fosfofruktokinaze, koja ima ključnu ulogu u procesu glikolize. Shodno tome, akumulira se glukozo-6 fosfat, koji zatim inaktivira heksokinazu 2, dovodeći do smanjenog preuzimanja glukoze u ćelije skeletnih mišića (21). Pored toga, porast koncentracije masnih kiselina u mišićima dovodi do povećanja koncentracije metabolita masnih kiselina (diacilglicerola /DAG/, acil-CoA i ceramida), koji potom mogu da aktiviraju kaskadu serin/ treonin kinaza, čime se fosforilišu ostaci serina i tirozina na IRS-1 i IRS-2 (IRS, supstrat za insulinski receptor /engl. insulin receptor substrates/). Time se smanjuje sposobnost IRS da aktivira fosfatidil-inozitol-3 kinazu (PI-3K), što dodatno redukuje transport glukoze u ćelije skeletnih mišića (22).

Prolongirano eksponiranje povećanoj količini SMK u gojaznih osoba ometa insulin da redukuje povećano stvaranje glukoze u jetri (Slika 1) (19).

Mehanizam koji stoji u osnovi akumulacije TG u jetri i razvoja hepatičke insulinske rezistencije je sličan razvoju insulinske rezistencije u skeletnim mišićima. $S$ tim u vezi, ustanovljeno je da porast intracelularne koncentracije DAG dovodi do aktivacije protein kinaze C (PKC), čime se smanjuje kinazna aktivnost insulinskog receptora. Sledstveno tome, dolazi do smanjene fosforilacije tirozinskih rezidua IRS-2, što dalje dovodi do redukcije PI3K aktivnosti, koja se nalazi u osnovi smanjenja aktivnosti glikogen sintaze pod uplivom insulina. Tim putem se smanjuje preuzimanje glukoze u jetri. Nasuprot tome, usled smanjenog supresivnog efekta insulina na stvaranje glukoze u jetri nastaje povećana hepatička produkcija glukoze, što sveukupno dovodi do porasta koncentracije glukoze u krvi (21).

NAFLD i nealkoholni steatohepatitis (NASH, engl. nonalcoholic steatohepatitis) predstavljaju dve najzastupljenije bolesti jetre povezane sa insulinskom rezistencijom (23-27). Mnogi činioci mogu da remete signalnu kaskadu insulina i time olakšaju nastanak insulinske rezistencije i NAFLD (SMK, faktor tumorske nekroze-alfa /TNF- $\alpha$ /, nukleusni faktor-kapa B /NF- $\kappa B /$, ceramidi, jun-N-terminalna kinaza-1/JNK-1/, supresori citokinske signalizacije /SOCS/ i citohromni enzimski sistem CYP2E1) $(24,28)$. Pokazano je da u stanjima insulinske 


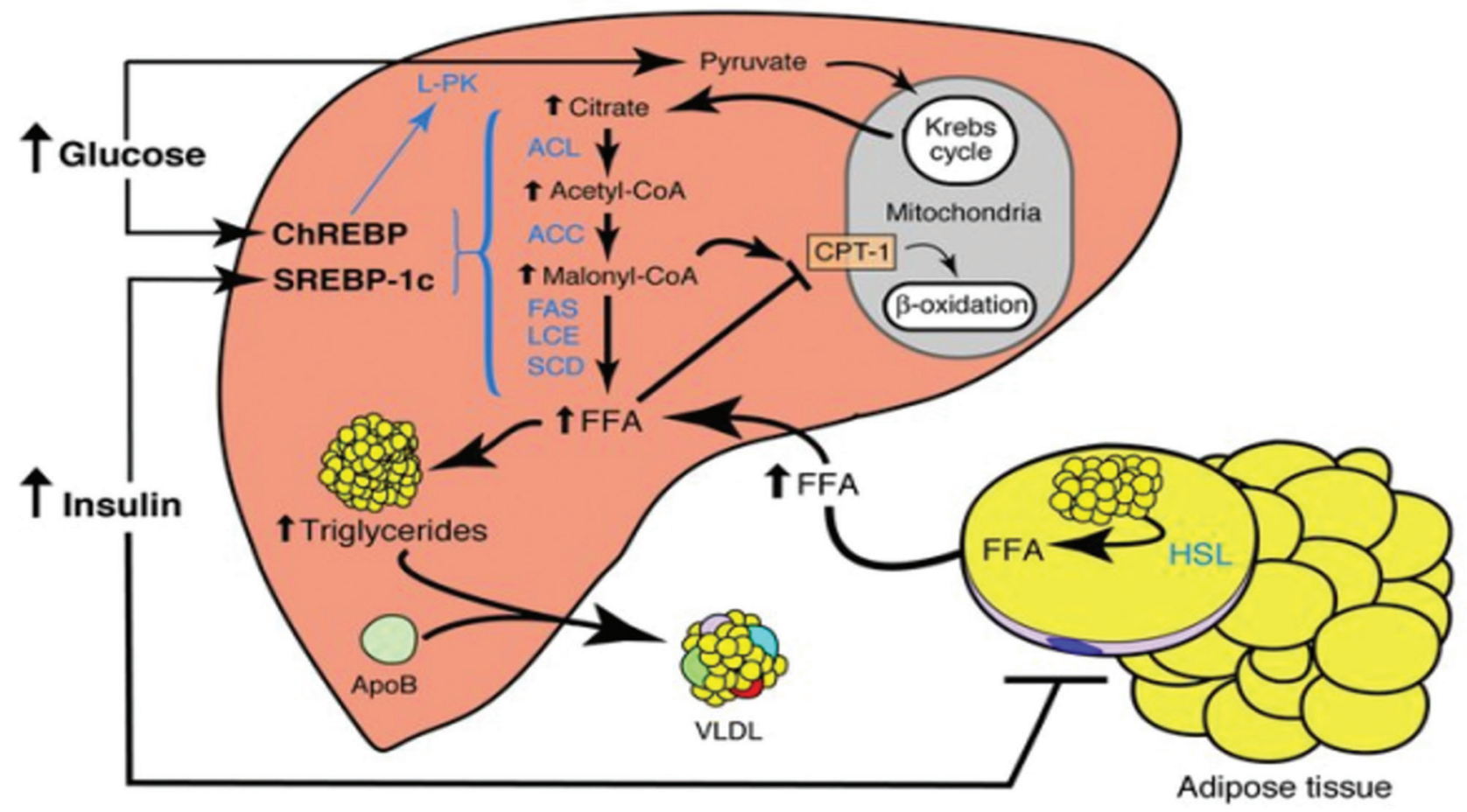

Slika 1. Uticaj slobodnih masnih kiselina na metabolizam glukoze

Picture 1. Influence of free fatty acids on glucose metabolism

rezistencije hiperinsulinemija dovodi do ushodne regulacije transkripcijskog faktora za protein-1c koji vezuje sterol-regulacijski element (SREBP-1c, engl. sterol regulatory element-binding protein), koji ima ključnu ulogu $\mathrm{u}$ regulaciji gena uključenih u de novo lipogenezu (28). Hiperinsulinemija dovodi i do inhibicije $\beta$-oksidacije masnih kiselina, što dalje doprinosi akumulaciji masti u hepatocitima i nastanku NAFLD (Slika 1) (24).

Insulinsku rezistenciju karakteriše onemogućenost insulina da suprimira lipolizu u masnom tkivu. Višak SMK, koji na ovaj način nastaje, transportuje se putem krvi uglavnom do skeletnih mišića i jetre. U jetri se, potom, vrši oksidacija jednog dela SMK, dok se preostali njihov sadržaj reesterifikuje u formi TG. U sledećem metaboličkom koraku, stvoreni TG u vidu lipoproteina vrlo male gustine (VLDL, engl. very low density lipoprotein) se sekretuju u cirkulaciju, pri čemu višak TG ostaje u hepatocitima doprinoseći nastanku steatoze (19). Nedavna istraživanja na ljudima i animalnim modelima ukazuju da se akululacija TG u vidu masnih kapljica u hepatocitima odvija paralelno sa oštećenjem insulinskih signalnih puteva (24). Osim toga, smatra se da nakupljeni TG u jetri mogu da kompromituju hepatičku cirkulaciju kompresijom sinusoida usled nekroze hepatocita (21).

Poznato je da višak masnog tkiva olakšava razvoj insulinske rezistencije posredstvom preko 100 biološki aktivnih molekula koje sekretuju adipociti (adipokini / leptin, adiponektin, rezistin, hemerin, omentin, apelin, i dr., masne kiseline, citokini, holesterol, steroidni hormoni i prostaglandini) (Slika 2) (29).
Utvrđeno je, takođe, da različiti stimulusi dovode do prekomernog stvaranja adipokina u gojaznih osoba (povećanje telesne mase, hipoksija usled većeg rasta masnog tkiva u odnosu na angiogenezu, oksidacijski stres, i dr.), koji zatim olakšavaju inflamaciju krvnih sudova $(17,30)$. Kardiomiociti genetski gojaznih $(o b / o b)$ miševa ispoljavaju insulinsku rezistenciju i poremećaje delovanja insulina (17).

Kod gojaznih osoba prekomerne naslage masnog tkiva mehanički vrše pritisak na krvne sudove, što uzrokuje otežan rad srca, dok se sa druge strane usled gojaznosti povećava i sama površina organizma, pa je potrebna i veća količina krvi za njegovu perfuziju. Da bi organizam sa prekomernim masnim naslagama zadovoljio svoje uvećane metaboličke potrebe, volumen krvi koja cirkuliše i minutni volumen srca se povećavaju. Povećanje minutnog volumena srca kod gojaznih osoba uglavnom potiče od količine krvi koja se ispumpava iz srca pri kontrakciji, iako je zbog povećane aktivnosti simpatičkog autonomnog nervnog sistema (SANS) povećan i puls srca. Kod takvih osoba, usled povećanog volumena krvi dolazi do dilatacije i povećane napregnutosti zida leve komore, što zatim dovodi do njene hipertrofije (31). Uz to, pokazano je i postojanje pozitivne korelacije između mase tela i srca. Masne ćelije se nagomilavaju između mišićnih vlakana ili dovode do degeneracije kardiomiocita, što za posledicu ima poremećaje sprovođenja ćelijskih signala u samom srcu (32).

Gojazne osobe (indeks telesne mase /BMI, engl. body mass index $/>30 \mathrm{~kg} / \mathrm{m}^{2}$ ) imaju dva do tri puta veći rizik od smrti u odnosu na osobe sa normalnom telesnom masom, dok 


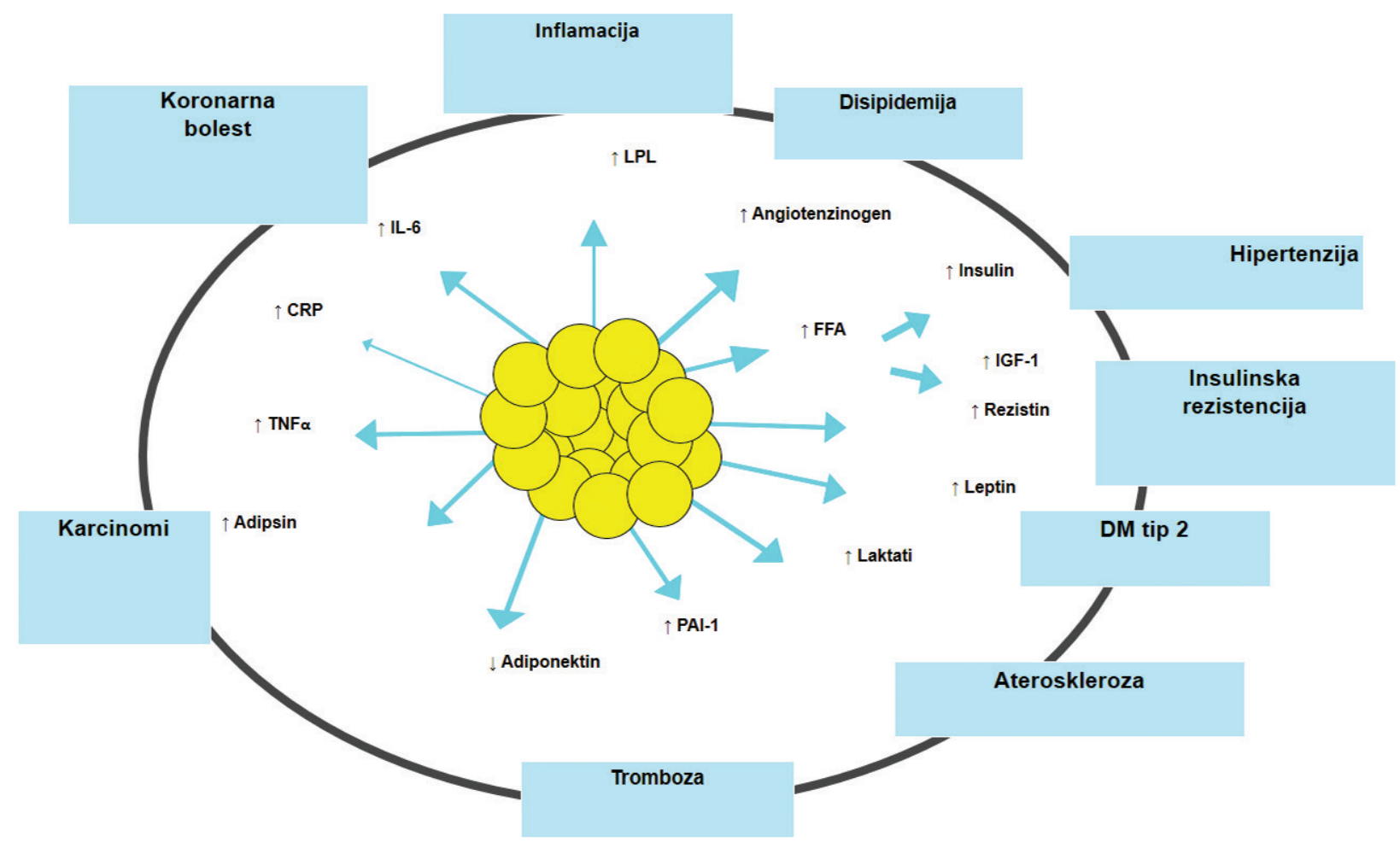

Slika 2. Biološki aktivni molekuli koje sekretuju adipociti

Picture 2. Adipocyte-derived biological active molecules

preterano gojazne osobe $\left(\mathrm{BMI}>35 \mathrm{~kg} / \mathrm{m}^{2}\right)$ kraće žive za pet do dvadeset godina u odnosu na osobe sa normalnom telesnom masom istog pola i godina (5). Međutim, kod pacijenata sa višim BMI koji pate od hroničnih oboljenja (koronarne bolesti, i dr.) zabeležene su veće šanse za preživljavanje nego kod pacijenata sa normalnom težinom. Patogeneza ovog fenomena, koji je u medicini označen kao „paradoks gojaznosti“, je nepoznata. Po sadašnjim shvatanjima on se može objasniti dodatnim bolestima koje se javljaju kod pacijenata sa niskim BMI (33).

\section{HiperTenZija}

Hipertenzija je tri do pet puta češća kod gojaznih osoba, u poređenju sa osobama koje imaju normalnu telesnu masu (5). Štaviše, ustanovljeno je da se rizik oboljevanja od hipertenzije linearno povećava sa porastom BMI, pri čemu je prevalenca hipertenzije dvostruko veća u abdominalnoj gojaznosti. Sa dobijanjem u težini tokom odraslog životnog doba krvni pritisak raste za $6.5 \mathrm{~mm} \mathrm{Hg}$ za svakih $10 \%$ porasta telesne težine. Poznato je da nastanku hipertenzije doprinose hiperinsulinemija putem povećane apsorpcije jona natrijuma $\left(\mathrm{Na}^{+}\right)$i vode, kao i aktivacija SANS i promene zida krvnog suda nastale dejstvom faktora rasta. Takođe, izmenjena aktivnost $\mathrm{Na}^{+} / \mathrm{K}^{+}$-ATPaze doprinosi patogenezi hipertenzije kod gojaznih osoba (34). Naime, pokazano je da u gojaznih ljudi SMK inhibiraju $\mathrm{Na}^{+} / \mathrm{K}^{+}$-ATPazu. U in vitro eksperimentima na izolovanim fragmentima membrane koje sadrže $\mathrm{Na}^{+} / \mathrm{K}^{+}$-ATPazu je pokazano da akumulacija SMK iznad određenog praga dovodi do promena fluidnosti membrane, što rezultuje promenom konformacije subjedinica $\mathrm{Na}^{+} / \mathrm{K}^{+}$-ATPaze. Smatra se da bi ove konformacijske promene mogle sprečiti hidrolizu ATP, i na taj način smanjiti aktivnost enzima. Takođe, postoji mogućnost da se SMK direktno vezuju za hidrofobne regione $\mathrm{Na}^{+} / \mathrm{K}^{+}$-ATPaze i na taj način menjaju njen afinitet za ligande, pre svega jone Na i K. S druge strane, SMK bi mogle da vezuju ove jone i na taj način ih sprečavaju da se vežu za Na+/K+-ATPazu (35).

Poznato je da insulin, indukuje vazodilataciju u skeletnim mišićima kod ljudi, i to mehanizmom koji uključuje aktivaciju $\mathrm{Na}^{+} / \mathrm{K}^{+}$-ATPaze lokalizovane na plazma membranama vaskularnih endotelnih i glatkih mišićnih ćelija (35). Takođe, insulin indukuje i značajno povećanje aktivnosti $\mathrm{Na}^{+} / \mathrm{K}^{+}$-ATPaze u srcu (36). Pokazano je da je ta stimulacija povezana sa translokacijom subjedinica $\mathrm{Na}^{+} / \mathrm{K}^{+}$-ATPaze, pre svega $\alpha_{2}$ izoforme, i to signalnim putevima koji uključuju protein kinazu B (Akt) i ekstracelularnim signalima regulisane kinaze 1 i $2($ ERK1/2) (36). Osim toga, različita istraživanja pokazuju da vezivanje insulina za insulinski receptor pokreće niz signalnih kaskada, koje između ostalog uključuju i povećanje aktivnosti PKC, za koju se smatra da je uključena u stimulaciju $\mathrm{Na}^{+} / \mathrm{K}^{+}$-ATPaze (37). Takođe, pokazano je da tretiranje vaskularnih glatkih mišićnih ćelija (VGMĆ) insulinom dovodi do povećanja nivoa prenosničke ribonukleinske kiseline (mRNK) za $\alpha_{2}$ subjedinicu $\mathrm{Na}^{+} / \mathrm{K}^{+}$-ATPaze (35).

\section{KoronARNA BOLEST}

AHA je gojaznost označila kao glavni faktor rizika za nastanak koronarne bolesti, imajući u vidu da je u više 
od dve trećine pacijenata koji imaju koronarnu bolest ustanovljena povećana telesna masa ili gojaznost (34, 38). Pokazano je da je rizik oboljevanja od koronarne bolesti prisutan kada su vrednosti BMI $>22 \mathrm{~kg} / \mathrm{m}^{2}$ za žene, a $23 \mathrm{~kg} / \mathrm{m}^{2}$ za muškarce. Takođe, abdominalna gojaznost pri svakom BMI povećava rizik oboljevanja od koronarne bolesti. Rizik za nastanak infarkta miokarda raste i sa dobijanjem u težini više od $5 \mathrm{~kg}$ posle dvadesete godine života (5). Osim toga, odnos TG/HDL je identifikovan kao pokazatelj insulinske rezistencije i metaboličkog sindroma, koji spadaju u nezavisne faktore rizika za nastanak koronarne bolesti (39). S tim u vezi, istraživanja su pokazala da je odnos TG/HDL veći od $4 \mathrm{mg} / \mathrm{dL}$ najmoćniji prediktor koronarne bolesti (40), kao i da vrednosti odnosa ovih lipidnih molekula koje su iznad 1.33 najbolje pokazuju prisustvo malih gustih lipoproteinskih čestica male gustine (LDL, engl. low density lipoprotein) (41). Naime, ustanovljeno je da su male guste LDL čestice izrazito aterogene, jer ih odlikuje naglašena moć penetracije u arterijski zid, smanjen afinitet za LDL receptore, produžen poluživot u plazmi i podložnost oksidacijskoj modifikaciji $(42,43)$. Osobe rezistentne na insulin imaju veliku koncentraciju dominantno malih gustih LDL čestica klase B, koje doprinose ranom oštećenju endotela i ubrzanju ateroskleroznog procesa (5). Takođe, dobro je poznato da je visok nivo TG, smanjen sadržaj HDL, kao i porast malih gustih LDL čestica povezan sa dijabetes melitusom tip 2 (44).

\section{KARDIOMIOPATIJA}

Gojaznim osobama preti dvostruko veći rizik za nastanak srčane insuficijencije u poređenju sa osobama koje imaju normalan BMI (45). Poznato je da gojazne osobe imaju koncentričnu hipertrofiju leve komore zbog hipertenzije i hiperkoagulabilnosti krvi. U odsustvu hipertenzije nastaje dilatacija i ekscentrična hipertrofija leve komore zbog povećanog minutnog volumena, odnosno hroničnog opterećenja volumenom. Gojaznost je označena kao nezavisni faktor rizika za dijastolnu disfunkciju leve komore, jer koncentrična hipertrofija leve komore narušava njeno punjenje i izaziva dijastolno popuštanje srca. Gojaznost narušava i sistolnu funkciju srca zbog smanjenog skraćivanja mišićnih vlakana i smanjenja ejekcione frakcije. Prema tome, gojaznost spada u glavne faktore rizika za razvoj kongestivne srčane insuficijencije (46). Osim toga, pacijenti sa uznapredovalom gojaznošću koji imaju srčanu insuficijenciju bez disfunkcije leve komore dijagnostikuju se kao pacijenti sa kardiomiopatijom povezanom sa gojaznošću (17). Skorašnje studije su pokazale da osim hipertenzije i koronarne bolesti, srčanu insuficijenciju može da izazove i hipertrofija leve komore povezana sa gojaznošću (38).

\section{Aritmije}

U gojaznih osoba su češće zastupljene ventrikularne ekstrasistole i fibrilacija pretkomora u poređenju sa normalno uhranjenim osobama, za šta su „okrivljene“ dijastolna srčana disfunkcija i hiperdinamska cirkulacija (46). Kod pacijenata sa poremećajem u radu srca često je prisutna i insulinska rezistencija, što takođe ukazuje na mogućnost da sistemska insulinska rezistencija i/ili specifičan poremećaj u signalnom putu insulina u miokardu, može da doprinese poremećajima u radu srca (17). Dokazi za ovu tvrdnju su dobijeni na osnovu eksperimenata na gojaznim pacovima sa insulinskom rezistencijom (47) i miševima sa specifičnom delecijom gena za receptor za insulin u srcu (48). Kod gojaznih pacova sa insulinskom rezistencijom pokazana je akumulacija lipida u srcu, disfunkcija kontraktilnosti leve komore i poremećena aktivacija signalnog puta receptora za insulin, PI3-K i protein kinazu B (PKB) (47).

\section{Tromboembolijska Bolest}

Duboka venska tromboza i plućna embolija češće se javljaju u gojaznih osoba, posebno u abdominalnoj gojaznosti (49). U patogenezi bolesti vena nogu učestvuju povećan intraabdominalni pritisak, smanjena fibrinoliza i povećana koncentracija medijatora zapaljenja $(29,50)$.

\section{INSULINSKA REZISTENCIJA I ATEROSKLEROZA}

Gojaznost kod adolescenata i odraslih osoba je povezana sa učestalom pojavom ranih ateroskleroznih lezija (17). Tako je, na primer, ateroskleroza koronarnih krvnih sudova ubrzana različitim mehanizmima koji su karakteristični za stanja gojaznosti (pojačan tonus SANS, naglašeno prisustvo SMK u cirkulaciji, povećan intravaskularni volumen i napregnutost vaskularnog zida, inflamacija i promene lipoproteina koje povećavaju aterogeni potencijal, i dr.) (38). Pored toga, poznato je da povećane količine insulina kod obolelih od metaboličkog sindroma, trudnica sa gestacijskim dijabetesom i dijabetičara (bolesnika sa dijabetesom tip 2, kao i onih sa tipom 1 ove bolesti, naročito sa manifestnom mikroalbuminurijom) deluju direktno na zid krvnog suda, dovodeći do nakupljanja lipida i bubrenja medije arterijskog zida. Istovremeno insulin uzrokuje proliferaciju vaskularnih glatkih mišićnih ćelija, pa na taj način deluje kao faktor rasta (44). Takođe, pokazano je da se vazodilatacijsko dejstvo insulina može potpuno blokirati primenom inhibitora azot monoksid sintaze (NOS), što sugeriše da se vazodilatacijski efekat insulina dominantno ostvaruje preko azot monoksida (NO). Tako, u fiziološkim uslovima povećavanjem nivoa NO putem PI3 kinazne aktivacije, insulin ublažava inflamacijsku reakciju endotela, inhibirajući ekspresiju adhezivnih molekula i smanjujući aktivnost inflamacijskih 
citokina, što se interpretira kao njegovo antiaterogeno delovanje. Međutim, u uslovima insulinske rezistencije stimulisan je ras mitogen aktivirani signalni put protein kinaze (MAP), tako da insulin ispoljava svoj aterogeni efekat (stimulacija ekstracelularne produkcije matriksa, ćelijski rast, mutacije u endotelu, i dr.). U takvim uslovima insulin stimuliše i produkciju inhibitora aktivatora plazminogena-1 (PAI-1) u VGMĆ, čime se inhibira fibrinoliza. Pokazano je, takođe, da kod osoba sa insulinskom rezistencijom postoji sinergizam između hiperinsulinemije i hiperlipidemije u odnosu na redukovanu elastičnost zida krvnog suda. Generalno posmatrano, progresija ateroskleroze kod osoba obolelih od metaboličkog sindroma i šećerne bolesti se objašnjava gubitkom insulinskih efekata koji se ostvaruju posredstvom PI3 kinaznog puta, pri čemu je očuvana stimulacija MAP kinaznog puta, koja dovodi do proliferacije VGMĆ, povećane produkcije endotelina-1 (ET-1), kolagena, faktora rasta i proinflamacijskih citokina (51).

\section{ENDOTELNA DISFUNKCIJA}

Endotelna disfunkcija, koja podrazumeva onemogućenost endotela da reguliše svoje osnovne funkcije (tonus krvnog suda, hemostazu, ćelijsku adheziju, balans elektrolita, i dr.), sa sadašnjeg aspekta sagledavanja dinamike aterogeneze se smatra ranim pokretačem ateroskleroznog procesa (52-57). U uslovima insulinske rezistencije prisutna su početna mikrovaskularna i makrovaskularna oštećenja kojima prethodi endotelna disfunkcija. U takvim uslovima u endotelu se zapaža poremećaj produkcije NO, koji je udružen sa poremećajem ravnoteže vaskularnih faktora, naročito odnosa između NO i ET1. Tako, početno oštećenje endotela uzrokuje povećanu produkciju solubilnih vaskularnih ćelijskih adhezivnih molekula (sVCAM), intracelularnih adhezivnih molekula (ICAM), ET-1, E-selektina, P-selektina, trombomodulina, fon Vilebrandovog (von Wilebrand) faktora, i dr., koju mnogi naučnici danas vide kao „markere endotelne aktivacije“ $(51,56,57)$.

\section{HipergLikeMiJA}

Hiperglikemija je okidač kaskadnih mehanizama koji dovode do oštećenja endotela krvnih sudova. Ona dovodi do promene funkcije oksidacijskih sistema stvarajući u vaskulaturi milje skon oksidaciji, čime se inhibira proliferacija endotelnih ćelija, tj. ometa reparacija oštećenja endotela. Takođe, hiperglikemija povećava adhezivnost trombocita stimulišući sintezu tromboksana, a smanjujući sintezu prostaciklina (58). Osim toga, hiperglikemija povećava sintezu DAG, i na taj način intracelularno dovodi do aktivacije signalnog sistema PKC. Shodno tome, dolazi do povećane produkcije endotelnih faktora rasta, kao što su vaskularni endotelni faktor rasta (VEGF, engl. vascular endothelial growth factor), epidermni faktor rasta (EGF, engl. epidermal growth factor) i transformišući faktor rasta beta (TGFß, engl. transforming growth factor $\beta$ ), koji potom dovode do migracije i proliferacije VGMĆ (56). Uz to, prekomerna ekspresija faktora rasta, koja nastaje pod uplivom hiperglikemije, doprinosi nastanku i razvoju novih krvnih sudova (neovaskularizacija /angiogeneza/) (30, 59). Važna posledica hiperglikemije je i povećana neenzimska glikacija belančevina (proces u kojem se glukoza hemijski veže za proteine bez uticaja enzima). Pokazano je da glikacija belančevina plazme ubrzava razvoj ateroskleroze u bolesnika sa insulinskom rezistencijom i dijabetesom. Kod ovih bolesnika stabilno glicirane belančevine plazme vežu se na odgovarajuće receptore na membranama endotelnih ćelija i monocita, što zatim aktivira ove ćelije (56).

\section{POREMEĆAJI LIPIDA I LIPOPROTEINA}

Štetan efekat izmenjenog lipidnog i lipoproteinskog profila na endotelnu funkciju obolelih od metaboličkog sindroma i dijabetesa (hipertrigliceridemija, porast LDL i sniženje HDL) dokumentovan je nizom istraživanja, koja su pokazala da je vazodilatacija krvnog suda u negativnoj korelaciji sa povišenim nivoom TG i LDL česti$\mathrm{ca}$, odnosno sniženim nivoom HDL partikula $(56,58)$. Ustanovljeno je, takođe, da hipertrigliceridemija dovodi do porasta koncentracije selektina i adhezivnih molekula (VCAM-1 /vaskularni adhezivni ćelijski molekul-1/ i ICAM-1 /intercelularni adhezivni molekul-1/), kao i poremećaja permeabilnosti endotelnih ćelija (55). Uz to, kao što je već ranije istaknuto, LDL čestice, postaju podložne oksidacijskoj modifikaciji, inhibirajući stvaranje NO. Istovremeno, oksidovane LDL čestice (oxLDL) aktivacijom citokina mogu da stimulišu proizvodnju solubilnih adhezivnih molekula $(43,53,60)$. Takođe, ove čestice moduliraju prostaglandin $\mathrm{I}_{2} /$ tromboksan $\mathrm{A}_{2}$ $\left(\mathrm{PGI}_{2} / \mathrm{TXA}_{2}\right.$ ) odnos, uzrokujući protrombogeno stanje (61). Osim toga, u stanjima hiperglikemije nastaje glikacija LDL čestica, koja zatim olakšava vezivanje ovih čestica za receptore čistače na membranama makrofaga i VGMĆ, što doprinosi ubrzanoj aterogenezi. Takođe, povećana koncentracija citokina koje produkuju makrofagi i VGMĆ potom podstiče proliferaciju endotela kapilara i time razvoj mikroangiopatije $(24,56)$.

\section{OKSIDACIJSKI STRES}

Oksidacijski stres se definiše kao povećano stvaranje oksidanasa i/ili slabljenje antioksidacijskih zaštitnih mehanizama (62). U stanjima insulinske rezistencije reaktivne kiseoničke vrste (RKV) nastaju redukcijom molekulskog kiseonika ili redukcijom vode, formirajući pri tom superoksidne anjone i hidroksilne radikale (Tabela 3) (63). 
Tabela 3. Reaktivne kiseoničke vrste

Table 3. Reactive oxygen species

\begin{tabular}{|c|c|c|}
\hline Vrsta & Ime & Poreklo \\
\hline${ }^{3} \mathrm{O}_{2}$ & Triplet kiseonika & Stabilni atmosferski oblik \\
\hline${ }^{1} \mathrm{O}_{2}$ & Singlet kiseonika & ${ }^{3} \mathrm{O}_{2}$, peroksidacija \\
\hline RH & Matični molekul & $\mathrm{RH}$ \\
\hline $\mathrm{R}^{*}$ & Slobodni radikal & RH \\
\hline $\mathrm{ROO}^{*}$ & Peroksi radikal & $\mathrm{R}^{\star}+\mathrm{O}_{2}, \mathrm{ROOH}$ \\
\hline${ }^{*} \mathrm{O}_{2} \mathrm{H}$ & Hidroperoksi radikal & ${ }^{*} \mathrm{O}_{2}^{-}+\mathrm{H}^{+}$ \\
\hline$* \mathrm{O}_{2}$ & Superoksid anjon radikal & $\mathrm{O}_{2}+\mathrm{e}^{-}$ \\
\hline${ }^{\star} \mathrm{OH}$ & Hidroksi radikal & $\mathrm{H}_{2} \mathrm{O}_{2}, \mathrm{H}_{2} \mathrm{O}$ \\
\hline $\mathrm{H}_{2} \mathrm{O}_{2}$ & Vodonik-peroksid & ${ }^{\star} \mathrm{O}_{2}$, biološko nastajanje \\
\hline $\mathrm{RO}^{*}$ & Alkoksi radikal & ROOH, ROOR \\
\hline $\mathrm{ROOH}$ & Hidroperoksid & $\mathrm{ROO},{ }^{1} \mathrm{O}_{2}$ \\
\hline ROOR & Peroksid & Peroksidacija \\
\hline$>\mathrm{c} / \mathrm{O} / \mathrm{c}<$ & Epoksid & Nezasićen $\mathrm{ROO}^{*}$ ili ROO* \\
\hline $\mathrm{ArO}^{*}$ & Peroksi i aroksi-radikali & Fenolski antioksidansi \\
\hline
\end{tabular}

Takođe, NO doprinosi povećanom stvaranju RKV i formiranju reaktivnih azotnih intermedijernih jedinjenja (Tabela 4) (64).
U uslovima hiperglikemije postoji pojačano pretvaranje glukoze u sorbitol uz smanjivanje količine redukovanog oblika nikotinamid adenin dinukleotid fosfata

Tabela 4. Biološki aktivni azotovi oksidi

Table 4. Biological active nitric oxides

$\begin{array}{cccc}\text { Simbol } & \text { Oksidacijsko stanje } & \text { Ime } & \text { Dejstvo } \\ \mathrm{NO}^{-} & +1 & \text { Nitroksil anjon } & \text { Miorelaksacijsko } \\ \mathrm{N}_{2} \mathrm{O} & +1 & \text { Azotsuboksid (oksidul) } & \text { Anestetičko } \\ \mathrm{NO}^{\mathrm{NO}} & +2 & \text { Azotmonoksid (azotoksid) } & \text { Vazodilatacijsko } \\ \mathrm{NO}^{+} & +3 & \text { Nitrozil katjon (nitrozonijum) } & \text { Mutageno, RAV } \\ \mathrm{NO}_{2}^{-} & +3 & \text { Nitrit } & \text { Oksidans } \\ \mathrm{N}_{2} \mathrm{O}_{3} & +3 & \text { Azottrioksid } & \text { Oksidans, RAV } \\ \mathrm{NO}_{2} & +4 & \text { Azotdioksid } & \text { Oksidans } \\ \mathrm{N}_{2} \mathrm{O}_{4} & +4 & \text { Azottetroksid } & \text { RAV } \\ \mathrm{ONOO}^{-} & +5 & \text { Peroksinitrit } & \text { Oksidans, antimikrobno, RAV } \\ \mathrm{NO}_{2}^{+} & +5 & \text { Nitril katjon (nitronijum) } & \text { Oksidans, RAV } \\ \mathrm{NO}_{3}^{-} & +5 & \text { Nitrat } & \text { Završni proizvod oksidacije }\end{array}$

RAV-Reaktivna azotna vrsta

Osim toga, do olakšanog nastanka oksidacijskog stresa u bolesnika sa insulinskom rezistencijom dovode hiperglikemija, povišen unos SMK, kao i izlaganje ultraviolentnom zračenju $(19,62)$. Štaviše, hiperglikemija predstavlja glavni faktor koji doprinosi nastanku oksidacijskog stresa u dijabetesu, jer je pokazano da stanje hiperglikemije utiče na stvaranje RKV i promenu oksidoredukcijske ravnoteže. Ove promene se događaju kroz nekoliko mehanizama (pojačan metabolizam glukoze preko poliolskog puta i povećanog stvaranja sorbitola, povećano intracelularno formiranje krajnjih produkata glikozilacije /AGE/, aktivacija PKC i povećana produkcija peroksidnih anjona u mitohondrijskom transportnom lancu elektrona) (62).
(NADPH), koji je ključni kofaktor za stvaranje najvažnijeg intraćelijskog antioksidansa, a to je redukovani glutation. Aktivacijom poliolskog puta, tj. nagomilavanjem sorbitola i njegove konverzije u fruktozu, kao i povećanjem odnosa NADH/NAD, može doći do aktivacije PKC i inhibicije enzima gliceraldehid 3-fosfat-dehidrogenaze (GAPDH) (Slika 3) (65).

Sledeći mehanizam doprinosa hiperglikemije oksidacijskom stresu predstavlja formiranje krajnjih produkata glikozilacije (AGE). AGE nastaju kovalentnim vezivanjem aldehida i ketona redukovanih šećerom za slobodne aminogrupe proteina, formirajući Šifove (Schiff) baze, koje spontano prelaze u stabilnije ketoamine („Amadori product“). Ova jedinjenja mogu biti direkt- 


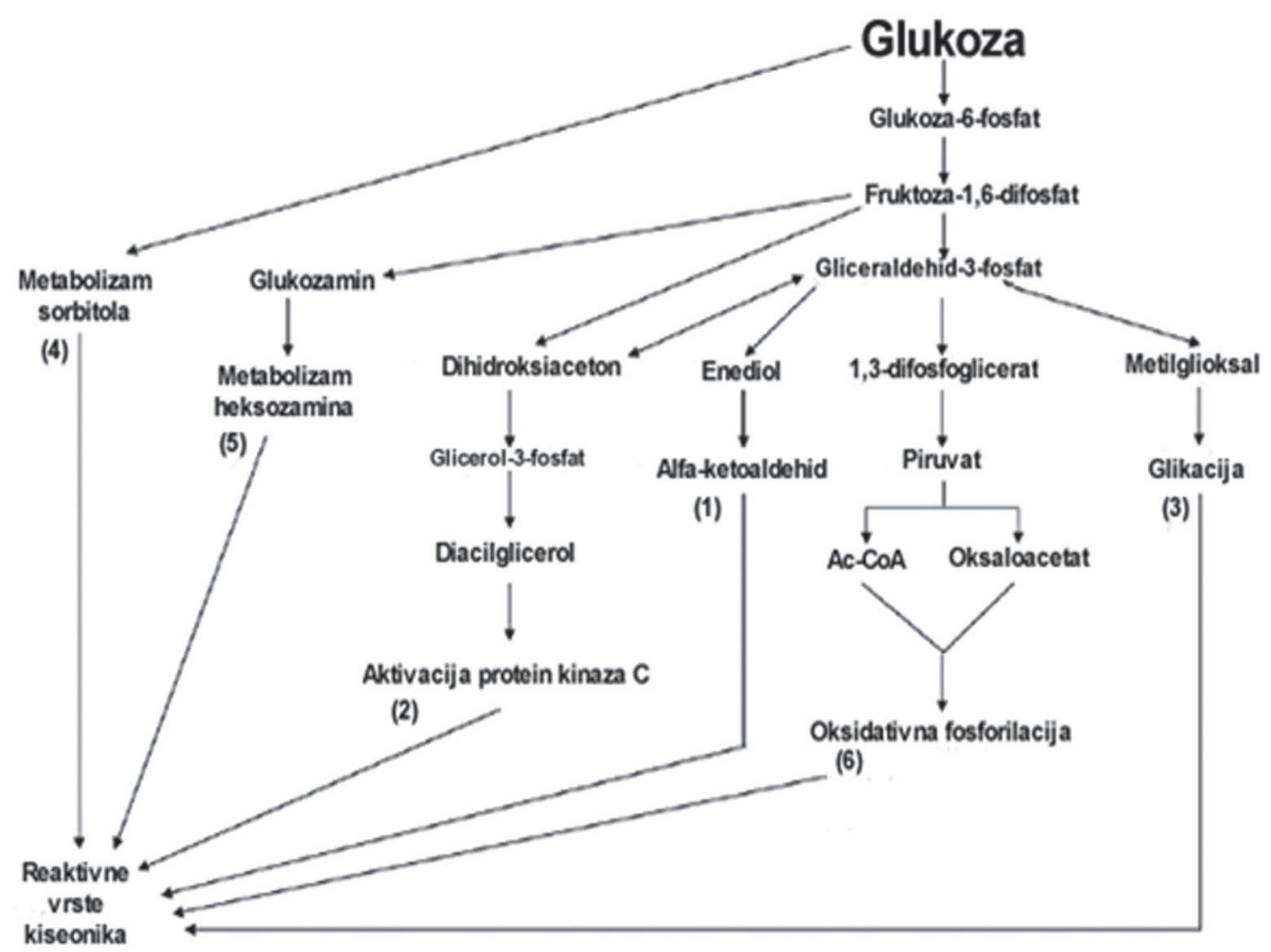

no pretvorena u AGE ili podleći autooksidaciji i formirati karbonilna intermedijerna jedinjenja (kao i sami molekuli glukoze), koja podležu kompleksnim hemijskim reakcijama stvarajući ireverzibilne AGE strukture (66). Utvrđeno je da AGE signalno pobuđuju ćelijske receptore za AGE (RAGE), koji su smešteni na površini ćelija. Ovi receptori su pored AGE zaduženi i za druge proinflamacijske molekule. RAGE se nalaze u velikom broju tkiva, a njihov broj i funkcija su naročito izraženi na mestima odvijanja ateroskleroznog procesa ili na mestima žarišta Alchajmerove bolesti u centralnom nervnom sistemu (CNS) (67). Jedna od najvažnijih posledica vezivanja RAGE-ligand kompleksa je produkcija intracelularnih RKV preko aktivacije sistema NADPH oksidaze. Produkovane RKV potom aktiviraju put ras/ MAPK, što dovodi do aktivacije NF-kB (66) sa posledičnim transkripcijskim aktiviranjem RAGE i mnogih drugih genski uslovljenih produkata povezanih sa aterosklerozom (68).

Hiperglikemija dovodi do direktne ili indirektne produkcije RKV preko aktivacije puta DAG-PKC (66). Familija PKC se sastoji od više različitih izoformi, od kojih je najveći deo aktiviran lipidnim „drugim glasnikom“ DAG. U uslovima hiperglikemije nastaje pojačano stvaranje dihidroksi-aceton-fosfata, koji se redukuje u glicerol-3 fosfat sa posledičnom pojačanom sintezom DAG. Aktivacija različitih PKC dovodi do niza promena u prenošenju ćelijskih signala. Tako je PKC- $\alpha$ moćni aktivator NADPH oksidaze, što posledično uzrokuje stvaranje RKV. Aktivacija PKC smanjuje produkciju NO inhibicijom endotelne azot monoksid sintetaze (eNOS) i indukuje ekspresiju VEGF, dovodeći do povećanja permeabilnosti krvnih sudova (25).

Hiperglikemija takođe može da dovede do inaktivacije antioksidacijskih proteina, kao što su bakar/cink superoksid dismutaze (Cu/Zn SOD, i dr.), smanjujući na taj način njihove antioksidacijske sposobnosti (62). Pored toga, bolesnici sa metaboličkim sindromom imaju izmenjen mitohondrijski metabolizam, skladištenje lipida, kao i povišene nivoe cirkulišućih SMK, što sve favorizuje oksidacijsko-redukcijski disbalans i posledični razvoj oštećenja jetre, srca i krvnih sudova (70). Slično tome, nedavna eksperimentalna istraživanja metaboličkog sindroma su takođe potvrdila da su srce (71) i jetra oštećeni organi i izvori poremećene oksidacijsko-redukcijske ravnoteže (72-74).

\section{ZAKLJUČAK}

Uprkos neprekidnom ovladavanju biomedicinskim tehnikama, naučnici su još uvek daleko od potpunog razumevanja poremećaja molekulskih funkcija i njihovog značaja u patogenezi metaboličkog sindroma. Stoga su 
potrebna dalja istraživanja molekulskih mehanizama ovog sindroma, kako bi se sprečio njegov nastanak, odnosno pronašao efikasniji terapijski pristup.

\section{NAPOMENA}

Rad je finansiran sredstvima iz projekta broj $175015 \mathrm{Mi}$ nistarstva prosvete, nauke i tehnološkog razvoja Republike Srbije.

\section{Literatura}

1. Gupta A, Gupta V. Metabolic syndrome: What are the risks for humans? Bio Sci Trends 2010;4(5):204-12.

2. Capasso I, Esposito E, Pentimalli F, Montella M, Crispo A, Maurea $\mathrm{N}$, et al. Homeostasis model assessment to detect insulin resistance and identify patients at high risk of breast cancer development: $\mathrm{Na}$ tional Cancer Institute of Naples experience. J Exp Clin Cancer Res 2013;32:14

3. Lepšanović $\mathrm{L}$, Lepšanović Lj. Povišen holesterol i ateroskleroza. Beograd, Velarta, 2009.

4. Harris MF. The metabolic syndrome. Aust Fam Physician 2013;42(8):524-7.

5. Micić D, Stamenković-Pejković D, Polovina S. Metabolički sindrom, diabetes mellitus tip $2 \mathrm{i}$ kardiovaskularni poremećaji. Medicinski glasnik. Specijalna bolnica za bolesti štitaste žlezde i bolesti metabolizma. Zlatibor 2010;(15)34:19-42.

6. Alberti KG, Zimmet P, Shaw J. IDF Epidemiology Task Force Consensus Group. The metabolic syndrome - a new worldwide definition. Lancet 2005;(366)9491:1059-62.

7. Grundy SM, Cleeman JI, Daniels SR, Donato KA, Eckel RH, Franklin $\mathrm{BA}$, et al. Diagnosis and menagement of the metabolic syndrome. An American Heart Association/National Heart, Lung and Blood Institute Scientific Statement. Circulation 2005;112:2735-52.

8. Amy ZF. Etiology of the metabolic syndrome. Curr Cardiol Rev 2007;3:232-9.

9. The metabolic syndrome. http://www.eufic.org/article/en/artid/metabolic-syndrome-epidemic

10. 1Juonala M, Magnussen CG, Berenson GS, Venn A, Burns TL, Sabin MA, et al. Childhood adiposity, adult adiposity and cardiovascular risk factors. N Engl J Med 2011;365:1876-85.

11. Westley RL, May FE. A twenty-first century cancer epidemic caused by obesity: the involvement of insulin, diabetes and insulin-like growth factors. Int J Endocrinol 2013;2013: 632461. doi: 10.1155/2013/632461.

12. Ma ZA, Zhao Z, Turk J. Mitochondrial dysfunction and beta-cell failure in type 2 diabetes mellitus. Exp Diabetes Res 2012; 2012: doi:703538.

13. Reaven GM. Banting lecture 1988: role of insulin resistance in human disease. Diabetes 1988;37:1595-607.

14. Kim-Dorner SJ, Deuster PA, Zeno SA, Remaley AT, Poth M. Should triglycerides and the triglycerides to high-density lipoprotein cholesterol ratio be used as surrogates for insulin resistance? Metabolism 2010;59(2):299-304.

15. Young LH. Diet-induced obesity obstructs insulin signaling in the heart. Am J Physiol Heart Circ Physiol 2010;298(2):306-7.

16. Cusi K. Role of obesity and lipotoxicity in the development of nonalcoholic steatohepatitis: pathophysiology and clinical implications. Gastroenterology 2012;142:711-25.

17. Sudar E, Zafirović S, Obradović M, Soskić S, Jovanović A, Stokić E, i sar. Gojaznost, rezistencija na insulin i kardiovaskularna oboljenja. Med Istraživ 2012;46(2):54-9.

18. Micić DD, Pejković D. Insulinska rezistencija i diabetes-etiopatogeneza, kliničke i terapijske karakteristike. U: Đorđević PB, urednik. Bazični i praktični problemi dijabetologije i bolesti metabolizma - Inovacije znanja XI. Medicinski fakultet Univerziteta u Beogradu, Beograd, 2005. 15-23.

19. Leamy AK, Egnatchik RA, Young JD. Molecular mechanisms and the role of saturated fatty acids in the progression of non-alcoholic fatty liver disease. Prog Lipid Res 2013;52:165-74.

20. olan CJ, Larter CZ. Lipotoxicity: why do saturated fatty acids cause and monounsaturated protect against it? J Gastroenterol Hepatol 2009;24:703-6.
21. Lei OL, Eric LK, Rosalind AC. Acyl-CoA synthesis, lipid metabolism and lipotoxicity. Biochim Biophys Acta 2010;1801:246-51.

22. Baron RB. Lipid disorders. In: McPhee SJ, Papadakis MA, eds. Current medical diagnosis and treatment. The McGraw-Hill Companies, New York, 2011. 1189-1200.

23. Cerović I, Mladenović D, Ješić R, Naumović T, Branković M, Vučević $\mathrm{D}$, et al. Alcoholic liver disease/nonalcoholic fatty liver disease index: distinguishing alcoholic from nonalcoholic fatty liver disease. Eur J Gastroenterol Hepatol 2013;25(8):899-904.

24. Gaggini M, Morelli M, Buzzigoli E, DeFronzo RA, Bugianesi E, Gastaldelli A. Non-alcoholic fatty liver disease (NAFLD) and its connection with insulin resistance, dyslipidemia, atherosclerosis and coronary heart disease. Nutrients 2013;5:1544-60.

25. Jornayvaz FR, Shulman GI. Diacylglycerol activation of protein kinase $\mathrm{C} \varepsilon$ and hepatic insulin resistance. Cell Metabol 2012;15:574-84.

26. Chavez-Tapia NC, Rosso N, Tiribelli C. Effect of intracellular lipid accumulation in a new model of non-alcoholic fatty liver disease. BMC Gastroenterology 2012;12:20 http://www.biomedcentral.com/1471$230 \mathrm{x} / 12 / 20$

27. Cusi K. Role of obesity and lipotoxicity in the development of nonalcoholic steatohepatitis: pathophysiology and clinical implications. Gastroenterology 2012;142:711-25.

28. Stanković MN, Mladenović DR, Đuričić I, Šobajić SS, Timić J, Jorgačević B, et al. Time-dependent changes and association between liver free fatty acids, serum lipid profile and histological features in mice model of nonalcoholic fatty liver disease. Arch Med Res 2014;45:116-24.

29. Bonsignore MR, McNicholas WT, Montserrat JM, Eckel J. Adipose tissue in obesity and obstructive sleep apnoea. Eur Respir J 2012;39:74667.

30. Vučević D, Radak Đ, Milovanović I, Radosavljević T, Mladenović D. Patofiziološki mehanizmi angiogeneze u aterogenezi. Med Pregl 2013;66(7-8):297-306

31. Vasan RS. Cardiac function and obesity. Heart 2003;89(10):1127-9.

32. Poirier P. Obesity and cardiovascular disease: pathophysiology, evaluation and effect of weight loss: an update of the 1997 American Heart Association Scientific Statement on Obesity and Heart Disease from the Obesity committee of the Council of Nutrition, Physical Activity and Metabolism. Circulation 2006;113(6):898-918.

33. Galal W. The obesity paradox in patients with peripheral arterial disease. Chest 2008;134(5):925-30.

34. Barbosa JA. Cardiovascular dysfunction in obesity and new diagnostic imaging techniques: the role of noninvasive image methods. Vasc Health Risk Manag 2011;7:287-95.

35. Jovanović A, Sudar E, Obradović M, Vujović P, Dacin Z, Ilić D, i sar. Regulacija srčane $\mathrm{Na}^{+} / \mathrm{K}^{+}$-ATPaze u stanjima gojaznosti, insulinske rezistencije i hipertenzije. Med Istraživ 2012;46(3):11-18.

36. Koricanac G, Tepavcevic S, Zakula Z, Milosavljevic T, Stojiljkovic M, Isenovic ER. Interference between insulin and estradiol signaling pathways in the regulation of cardiac eNOS and $\mathrm{Na}(+) / \mathrm{K}(+)$-ATPase. Eur $\mathrm{J}$ Pharmacol 2011;655(1-3):23-30.

37. Hatou S, Yamada M, Akune Y, Mochizuki H, Shiraishi A, Joko T, et al. Role of insulin in regulation of $\mathrm{Na}+-/ \mathrm{K}+$-dependent ATPase activity and pump function in corneal endothelial cells. Invest Ophthalmol Vis Sci 2010;51(8):3935-42.

38. Lopez-Jimenez F, Cortes-Bergoderi M. Update: systemic diseases and the cardiovascular system: obesity and the heart. Rev Esp Cardiol 2011;64(2):140-9.

39. Cordero A, AndrésE, OrdoňezB. Usefulness oftriglycerides-to-high-density lipoprotein cholesterol ratio for predicting the first coronary event in men. Am J Cardiol 2009;104(10):1393-7. 
40. Da Luz PL, Favarato D, Faria-Neto JR Jr, Lemos P, Chagas AC. High ratio of triglycerides to HDL-cholesterol predicts extensive coronary disease. Clinics (Sao Paulo) 2008;63(4):427-32.

41. Boizel R, Benhamou PY, Lardy B, Laporte F, Foulon T, Halimi S. Ratio of triglycerides to HDL cholesterol is an indicator of LDL particle size in patients with type 2 diabetes and normal HDL cholesterol levels. Diabetes Care 2000;23(11):1679-85.

42. Koba S, Hirano T, Ito Y. Significance of small dense low-density lipoprotein-cholesterol concentrations in relation to the severity of coronary heart diseases. Atherosclerosis 2006;189(1):206-14.

43. Vučević D, Radosavljević T, Mladenović D, Šteković J, Gajin P, Milovanović I, i sar. Lipidni profil u serumu kunića sa eksperimentalnom aterosklerozom. Med Čas 2010;44(4):9-15.

44. Kadić I, Kosi L. Povezanost odnosa TG/HDL, insulinske rezistencije i pojave i intenziteta koronarne bolesti kod pacijenata sa tipom 2 dijabetesa i nedijabetičara. Med Podmladak 2012;63(1-2):78-82.

45. Krum H, Abraham WT. Heart failure. Lancet 2009;373(9667):941-55.

46. Rana JS, Nieuwdorp M, Jukema JW. Cardiovascular metabolic syndrome-an interplay of obesity, inflammation, diabetes and coronary heart disease. Diabetes Obes Metab 2007;9:218-32.

47. Witteles RM, Fowler MB. Insulin-resistant cardiomyopathy clinical evidence, mechanisms and treatment options. J Am Coll Cardiol 2008;51(2):93-102.

48. Boudina S. Contribution of impaired myocardial insulin signaling to mitochondrial dysfunction and oxidative sress in the heart. Circulation 2009;119(9):1272-83.

49. WHO.Obesity and overweight. http://www.who.int/mediacentre/factsheets/fs131/en/index.html

50. Vučević D, Radosavljević T, Đorđević D, Mladenović D, Vesković M. The relationship between atherosclerosis and pulmonary emphysema. Med Pregl 2014;67(7-8):231-8.

51. Hajduković Z, Špirić Ž. Efekti korekcije insulinske senzitivnosti na neke vaskularne parametre. U: Đorđević PB, urednik. Bazični i praktični problemi dijabetologije i bolesti metabolizma - Inovacije znanja XI. Medicinski fakultet Univerziteta u Beogradu, Beograd, 2005. 31-9.

52. Vučević D, Radak Đ, Radosavljević T, Mladenović D, Milovanović I. Ateroskleroza u svetlu postojećih naučnih teorija. Med Istraž 2008;42(2):29-36.

53. Vučević D, Radak Đ, Radosavljević T, Mladenović D, Milovanović I. Fibrozni plak kao metabolički stadijum aterogeneze. Med Istraž 2009;43(1):35-47.

54. Sharma R, Rana A, Kumar C, Thakur S. Endothelium dysfunction, inflammation and cardiovascular disorder. Webmed Central Pharmaceutical Sciences. 2011;2(9):WMCOO2176.

55. Vučević D, Radak Đ, Radosavljević T, Mladenović D, Milovanović I. Zapaljenski proces u aterogenezi: nove činjenice o starom plamenu. Med Pregl 2012;65(9-10):388-95.

56. Frostegárd J. Immune mechanisms in atherosclerosis, especially in diabetes type 2. Front Endocrinol 2013;4:162-72.

57. Iantorno M, Campia U, Di Daniele N, Nisticó S, Forleo GB, Cardillo C, et al. Obesity, inflammation and endothelial dysfunction. J Biol Regul Homeost Agents 2014;28(2):169-76.

58. Rapp JH, Owens CD, Johnson MD. Blood vessel and lymphatic disorders. In: Mc Phee SJ, Papadakis MA, eds. Current Medical Diagnosis and Treatment. New York: Mc Graw Hill Companies; 2011. p. 446-69.
59. Noe HT, Michel MJB. Initiation of angiogenesis in atheroslerosis: smooth muscle cells as mediators of the angiogenic response to atheroma formation. Trends Cardiovasc Med 2011;21:183-7.

60. Jackson KG, Poppitt SD, Minihane AM. Postprandial lipemia and cardiovascular disease risk: interrelationships between dietary, physiological and genetic determinants. Atherosclerosis 2012;220(1):22-33.

61. Qu A, Shah YM, Manna SK, Gonzalez FJ. Disruption of endothelial peroxisome proliferator-activated receptor $\gamma$ accelerates diet-induced atherogenesis in LDL receptor-null mice. Arterioscler Thromb Vasc Biol 2012;32:65-73.

62. Valko M, Leibfritz D, Moncol J, Cronin MTD, Mazur M, Telser J. Free radicals and antioxidants in normal physiological functions and human disease. Int J Biochem Cell Biol 2007;39:44-84.

63. Schinzari F, Tesauro M, Rovella V, Galli A, Mores N, Porzio O, et al Generalized impairment of vasodilator reactivity during hyperinsulinemia in patients with obesity-related metabolic syndrome. Am J Physiol Endocrinol Metab 2010;299:E947-52.

64. Chen C, Jiang J, Lu JM, Chai H, Wang X, Lin PH, et al. Resistin decreases expression of endothelial nitric oxide synthase through oxidative stress in human coronary artery endothelial cells. Am J Physiol 2010;299:193-201.

65. Snel M, Jonker TJ, Schoones J, Lamb H, de Roos A, Pijl H, et al. Ectopic fat and insulin resistance: pathophysiology and effect of diet and lifestyle interventions. Int J Endocrinol 2012; doi:10.1155/2012/983814.

66. Basta G, Schmidt AM, De Caterina R. Advanced glycation end products and vascular inflammation: implications for accelerated atherosclerosis in diabetes. Cardiovasc Res 2004;63:582-92.

67. Osborn O, Olefsky JM. The cellular and signaling networks linking the immune system and metabolism in disease. Nat Med 2012;18:363-74.

68. Murphy R, Carroll RW, Krebs JD. Pathogenesis of the metabolic syndrome: insights from monogenic disorders. Mediators Inflamm 2013; doi:10.1155/2013/290214

69. Skalicky J, Muzakova V, Kandar R, Melovn M, Rousar T, Palicka V. Evaluation of oxidative stress and inflammation in obese adults with metabolic syndrome. Clin Chem Lab Med 2008;46:499-505.

70. Grattagliano I, Palmieri V, Portincasa P, Moschetta A, Palascioano G. Oxidative stress risk factors associated with metabolic syndrome: a unifying hypothesis. J Nutr Bioch 2008;19:491-504.

71. Vučević D, Mladenović D, Ninković M, Aleksić V, Stanković MN, Stanković $\mathrm{M}$, et al. The effects of caloric restriction against ethanol-induced oxidative and nitrosative cardiotoxicity and plasma lipids in rats. Exp Biol Med (Maywood) 2013;238:1396-1405.

72. Stanković M, Mladenović D, Ninković M, Vučević D, Tomašević T, Radosavljević T. Effects of caloric restriction on oxidative stress parameters. Gen Physiol Biophys 2013;32:277-83.

73. Mladenović D, Ninković M, Aleksić V, Šljivančanin T, Vučević D, Todorović V, et al. The effect of calorie restriction on acute ethanol-induced oxidative and nitrosative liver injury in rats. Environ Toxicol Pharmacol 2013;36(2):296-302.

74. Jorgačević B, Mladenović D, Ninković M, Prokić V, Stanković MN, Aleksić V, et al. Dynamics of oxidative/nitrosative stress in mice with methionine-choline-deficient diet-induced nonalcoholic fatty liver disease. Hum Exp Toxicol 2014;33(7):701-9. 